\title{
Predicted impact of climate change on the distribution of the Critically Endangered golden mantella (Mantella aurantiaca) in Madagascar
}

\author{
Wayne M. Edwards ${ }^{1,2}$, Michael J. Bungard ${ }^{3}$, Eddie F Rakotondrasoa ${ }^{4}$, Pierre Razafindraibe ${ }^{4}$ \\ Raphali R Andriantsimanarilafy ${ }^{4}$, Julie H Razafimanahaka ${ }^{4}$, \& Richard A. Griffiths ${ }^{1}$

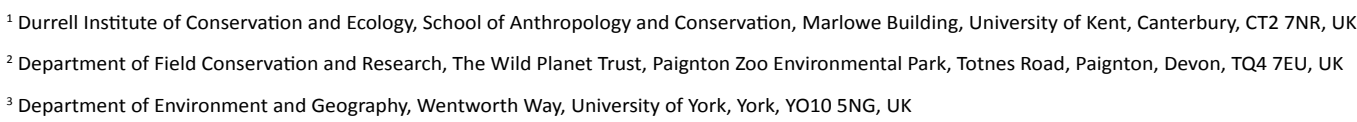

\begin{abstract}
The impact of climate change on Malagasy amphibians remains poorly understood. Equally, deforestation, fragmentation, and lack of connectivity between forest patches may leave vulnerable species isolated in habitat that no longer suits their environmental or biological requirements. We assess the predicted impact of climate change by 2085 on the potential distribution of a Critically Endangered frog species, the golden mantella (Mantella aurantiaca), that is confined to a small area of the central rainforest of Madagascar. We identify potential population distributions and climatically stable areas. Results suggest a potential south-eastwardly shift away from the current range and a decrease in suitable habitat from 2110 $\mathrm{km}^{2}$ under current climate to between $112 \mathrm{~km}^{2}-138 \mathrm{~km}^{2}$ by the year 2085 - less than $7 \%$ of currently available suitable habitat. Results also indicate that the amount of golden mantella habitat falling within protected areas decreases by $86 \%$ over the same period. We recommend research to ascertain future viability and the feasibility of expanding protection to newly identified potential sites. This information can then be used in future conservation actions such as habitat restoration, translocations, re-introductions or the siting of further wildlife corridors or protected areas.
\end{abstract}

Keywords: Conservation, SDM, amphibian, montane, rainforest, protected area

\section{INTRODUCTION}

$\mathrm{M}$ adagascar is one of the world's mega-biodiversity hotspots, with extremely high levels of endemism across the island (Myers et al., 2000; Vieilledent et al., 2013). Amphibians follow the trend with 314 assessed frog species, $99 \%$ of which are endemic (IUCN, 2021), and there are potentially many more yet to be described (Glaw \& Vences, 2007). Most species are located within the Eastern rainforest belt (Glaw \& Vences, 2007). However, forests across Madagascar are being depleted at an alarming rate, i.e. from 1953 to 2014 forested land cover decreased from $27 \%$ to $15 \%$ (Brown et al., 2015; Vieilledent et al., 2018). Forest fragments that remain are also decreasing in size with mean distance to forest edge dropping from $1.5 \mathrm{~km}$ to $300 \mathrm{~m}$ respectively (Brown et al., 2015; Vieilledent et al., 2018). Fragmentation of already degraded forest areas may impede the movement of species with low vagility between habitat patches, increase access for loggers or hunters, expose deep forest species to forest edge effects, increase competition for limited resources, or result in habitat patches too small to sustain viable populations (Cushman, 2006; Echeverria et al., 2006; Vieilledent et al., 2018).
Predictions for climate change across Madagascar suggest a rise in temperature of $1.1{ }^{\circ} \mathrm{C}-2.6^{\circ} \mathrm{C}$ by 2050 (Tadross et al., 2008). Temperatures vary along a gradient from north to south, with the lowest rises predicted in the northern and coastal areas, and highest rises in the southern spiny forest region (Hannah et al., 2008). Rainfall is predicted to increase across the island except along the south-east coast where it will become drier in winter months (Hannah et al., 2008). According to Seidl et al. (2017), climate change has the potential to affect forests in complex ways i.e. an increase in temperature and lower rainfall may lead to higher instances of tree die-off, forest fires, fuel build up, or insect abundance. Under hotter and wetter conditions, soil erosion, runoff and sedimentation become more likely (Seidl et al., 2017). Deforestation and climate change may therefore act synergistically driving species to shift their range to areas with more favourable conditions (Raxworthy et al., 2008). Historically, large tracts of contiguous forest may have made dispersal to higher, cooler or more climatically stable areas easier. However, with many montane forest areas in Madagascar now highly fragmented, dispersal for some species is difficult, if not impossible (Brown et al., 2015). 
Golden mantellas (Mantella aurantiaca) are Critically Endangered montane forest dwelling frogs from the Central Eastern Rainforest areas of Mangabe and Analamay in Madagascar (Piludu et al., 2015; Edwards et al., 2019). They are found at altitudes of between $900 \mathrm{~m}$ and $1000 \mathrm{~m}$ asl and the area of suitable habitat occupied by this species is low at around $10 \mathrm{~km}^{2}$. A recent survey by Piludu et al. (2015) found 139 breeding sites, many of which were in areas under threat from agricultural expansion, industrial or artisanal mining, or collection for the pet trade, with the majority in areas already classed as protected.

Climate change may exacerbate problems faced by golden mantellas as they are already found at altitudes close to the summits of the slopes they inhabit, leaving no real opportunity for dispersal to higher, cooler altitudes. It is clear there are few in-situ conservation management options remaining: the frogs either adapt to climate change, or alternative suitable habitat needs to be restored in areas where it is required. To this end Species Distribution Modelling (SDM) can play an important part in identifying suitable areas for the possible translocation or reintroduction of golden mantella populations. SDM is the process of exploring the relationships between species distribution and associated environmental and habitat variables, and then predicting spatial relationships (Márcia-Barbosa et al., 2013 Bateman et al., 2013; Cao et al., 2013; Meynard et al., 2013; Rodriguez-Rey et al., 2013). We follow several other authors (Blank \& Blaustein, 2012; Chunco et al., 2013; Groff et al., 2014; Sharifi et al., 2017) in using SDM to identify and prioritise optimum habitat requirements, where potential anthropogenic disturbance and climate change impacts are at their lowest. Results can then be used to guide future management decisions regarding the placement of protected areas and the reintroduction or translocation of golden mantellas to favourable sites if needed.

\section{METHODS}

\section{Data collection and study area}

The aim of modelling was to explore potential suitable habitat to inform broader conservation decisions, in an area around Moramanga Province, Madagascar. Records of golden mantella sightings were collected by Madagasikara Voakajy research teams from ten sites within the protected areas of Mangabe, each containing or bordering known golden mantella breeding ponds. Nine of these sites were surveyed between 28 November 2014 - 12 December 2014, and the tenth earlier on in the year in March 2014. These periods correspond to the main breeding activity periods for this species. All surveys took place between $0700-1400 \mathrm{hrs}$ each day, one visit per forest. The surveys were centered on breeding pools located in shallow depressions within the forest.

\section{Species distribution modelling}

A total of 198 golden mantellas were recorded across the ten surveyed sites in Moramanga. In order to meet the assumptions of Maxent with environmental data and reduce spatial bias, we needed to reduce golden mantella presence data to one observation (one frog) per $250 \mathrm{~m}$ grid square (See: Elith et al., 2011). In doing so we reduced presence data to 98 Mantella aurantiaca locations at a $250 \mathrm{~m}$ spatial grain.

Remotely sensed data have greatly improved over recent years and now provide good, useable information to answer ecological questions (Pfeifer et al., 2012). We used remotely sensed data for climate and habitat variables to model current and future distributions for golden mantellas. Four climate variables were selected from Worldclim (Hijmans et al., 2005) due to their biological relevance to frogs and because of low intercorrelation (Pearson's $r<0.7$ ); Temperature seasonality ( ${ }^{\circ} \mathrm{C} \times 10$, standard deviation over monthly values); Mean temperature of the warmest quarter $\left({ }^{\circ} \mathrm{C}\right.$ $x$ 10, any consecutive 3-month period); Mean rainfall of the wettest quarter ( $\mathrm{mm}$, any consecutive 3-month period); Maximum water deficit ( $\mathrm{mm}$, consecutive months that experience rainfall < monthly PET (Potential Evapotranspiration, Hargreaves method), over which the shortfall in rain is accumulated. Raster development followed Pfeifer et al. (2018). This variable is also defined by Stephenson (1998) as the amount of water by which potential evapotranspiration (PET) exceeds actual evapotranspiration (AET).

Four habitat variables were selected because of their potential relevance to amphibians; Canopy height, Topographic wetness index, Landcover and Enhanced Vegetation Index (EVI). Canopy height (m) was sourced from NASA Earthdata (Simard et al., 2011; ORNL DAAC, 2017). Topographic wetness is a measure of the potential for water to flow into the grid cell and of how likely it is to remain there. We built the raster by using a $30 \mathrm{~m}$ filled Aster Digital Elevation Model (NASA/METI/AIST/Japan Spacesystems and U.S./Japan ASTER Science Team, 2001). From this we made two further rasters using ArcGIS 10.3.1 (ESRI, 2015) which described the accumulation of water flow (w) from the surrounding pixels and slope(s). We then used these respective rasters to calculate Topographic index from $\mathrm{Ln}(900 \mathrm{w} / \tan (\mathrm{s})$ and values were normalised. Landcover classes are categorical variables such as cropland, forest etc, represented as a percentage of a grid square and interpolated from $1 \mathrm{~km}$ to $250 \mathrm{~m}$ resolution using bilinear interpolation (weighted distance average) in ArcGIS 10.3.1 (ESRI, 2015) (Arino, et al., 2012); Enhanced vegetation index reflects variation in canopy structure and architecture (Vieilledent et al., 2018). Mean annual Enhanced Vegetation Index is from 16-day $250 \mathrm{~m}$ MODIS MOD13Q1 data from the years 2007-2017 (Didan, et al., 2015).

Future climate projections (Representative Concentrations Pathways (RCP) 4.5 and 8.5) were sourced from AFRICLIM (Platts et al., 2015). RCP are greenhouse gas concentration projection scenarios adopted by the Intergovernmental Panel on Climate Change so that climate change studies and modelling might use a set of standardised measures (Van Vuuren et al., 2011). RCP 4.5 assumes $\mathrm{CO}_{2}$ concentrations will continue to rise 
a)

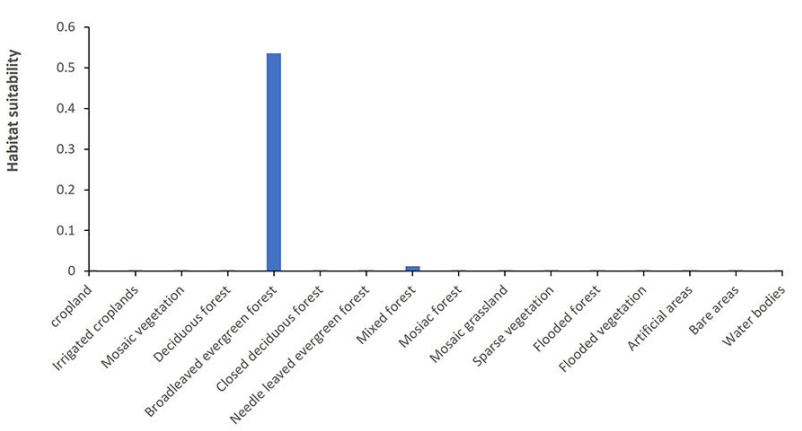

b)

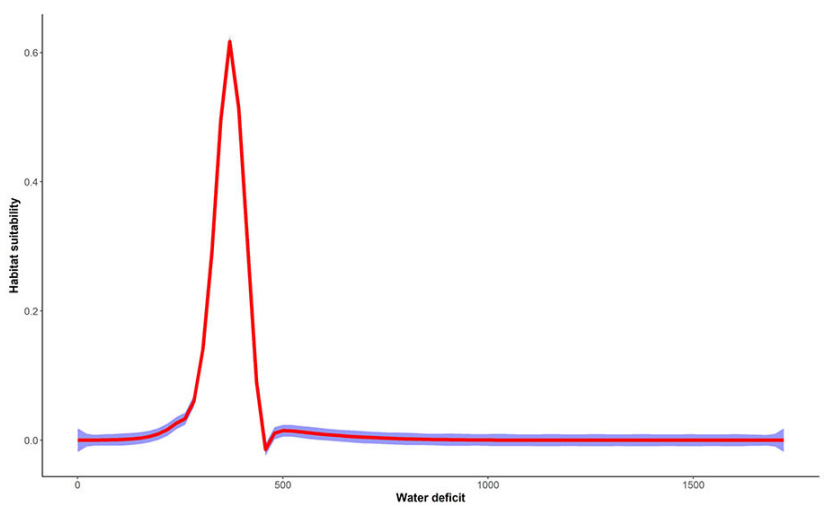

Figure 1. Habitat suitability in relation to (a) landcover categories and (b) water deficit. Broadleaved evergreen forest and the length and severity of the dry season are the main drivers for the distribution of golden mantellas. Habitat suitability is given as between 0 (unsuitable) and 1 (highly suitable) and is based on variables initially entered in to MaxEnt. Water deficit (Wd) is the amount of water by which potential evapotranspiration exceeds actual evapotranspiration (derived from remote sensed satellite data) and is indicative of the severity of the dry season. The red line is the response curve (fit of the data), the blue line is the standard deviation. Our model suggests habitat suitability is high where water deficit remains low at around $400 \mathrm{~mm}$ i.e. associated with a short dry season.

to approximately 650 parts per million (ppm) by 2100 and stabilise thereafter (Van Vuuren et al., 2011). RCP 8.5 assumes rising $\mathrm{CO}_{2}$ concentrations to approximately 1370 ppm by 2100 (Van Vuuren et al., 2011).

Potential distributions were modelled using Maxent (v. 3.3.3k), a standard SDM technique using presenceonly data (Hernández et al., 2006; Pearson, 2007). Climate data were at $1 \mathrm{~km}$ resolution and habitat/vegetation data were at $250 \mathrm{~m}$ resolution, but for Maxent to work, both sets of data must be at the same scale. All $1 \mathrm{~km}$ data were therefore interpolated to $250 \mathrm{~m}$ portions, ensuring that values in each grid cell were maintained, e.g. if the $1 \mathrm{~km}$ grid square had a temperature of $20^{\circ} \mathrm{C}$, then all of the $250 \mathrm{~m}$ grid squares that make up that $1 \mathrm{~km}$ grid square would also be at $20^{\circ} \mathrm{C}$. Habitat variables were included as static variables (a variable that may change with climate change, but we are unable to predict the amount of change due to confounding factors such as anthropogenic disturbance within the distribution models for future scenarios). We used static variables as it is difficult to model dynamic variable change (e.g. vegetation growth) along with projected climate change. Although we understand vegetation will alter with climate, preliminary runs of the model suffered from the exclusion of vegetation variables altogether: we therefore chose to keep these static variables (Stanton et al., 2012).

Maxent makes several assumptions that affect the performance of the model (Phillips et al., 2006) and constrain final spatial patterns of species distribution. We therefore used a regularisation multiplier, described by Merow et al. (2013) as placing a Bayesian priori distribution on model parameters (i.e. using current knowledge and reasonable expectation to predict potential distribution). The regularisation multiplier effectively constrains or relaxes the fit around the data balancing the need for both accuracy of predictions and generality (Elith et al., 2011). Prior to running final models, we adjusted the regularisation multiplier and selected the most appropriate model using Akaike Information Criteria (AIC) (Warren et al., 2010; Warren \& Seifert, 2011). In addition, the final models were cross-validated ten times, and to determine drivers of distribution, we jack-knifed environmental data (Phillips et al., 2006). All other settings were set to default. We used Albers Africa Equal-area projection to equalise grid cell size (Elith et al., 2011) to $0.250 \mathrm{~m}^{2}$ and an appropriately scaled kernel density bias file was used to restrict the placement of pseudo-absences (Fourcade et al., 2014). Maxent is a presence-only modelling system based upon reliable species sightings, which means it does not utilise any known absence information. Instead, it fills the gaps using pseudo-absences (estimated absences). Pseudoabsences are estimated by taking known presence data for large numbers of similar species (kernel density file) and then determining the probability of finding a given species across different areas and habitat. This research used a kernel density file constructed from amphibian sightings across Madagascar. To identify areas of suitable habitat in current and future scenarios, we used maximum test sensitivity plus specificity logistic threshold which minimises error between specificity and sensitivity (false positives and false negatives) (Liu et al., 2005). The Habitat Suitability Index (Fig. 1), i.e. how suitable an area is for a species based upon the variables entered into the model, was calculated using Maxent. To describe the current golden mantella area of occurrence we developed a Minimum Convex Polygon (MCP) based on the raw data for $M$. aurantiaca occurrences and then added a $10 \mathrm{~km}$ buffer (e.g. Smith \& Green, [2005] suggest maximum dispersal distances for most amphibians would not exceed far beyond $10 \mathrm{~km}$ ), to create an over-estimate of current area (Fig. 2). Habitat suitability was projected across Moramanga district to identify potential areas 


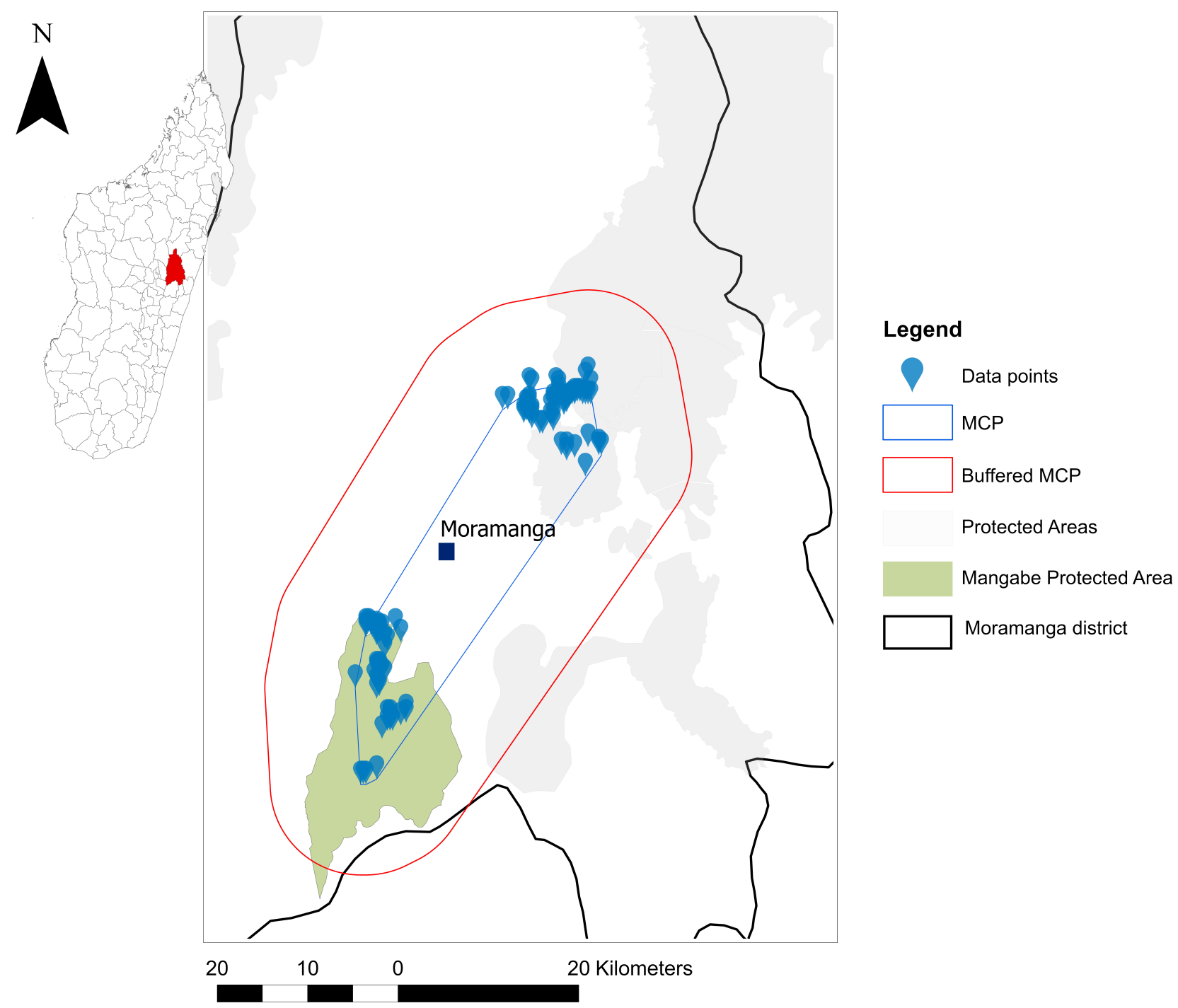

Figure 2. Study area. Data points for golden mantella are shown, from which a Minimum Convex Polygon (MCP) was developed. A $10 \mathrm{~km}$ buffer (buffered MCP) was used to account for potential maximum dispersal of frogs when assessing future climate scenarios after Species Distribution Modelling.

of suitable habitat for current conditions and whether suitable habitat fell within the MCP.

For each climate scenario we used a metric from Bungard et al. (2020) to measure the level of imperilment based on the index of net change $(N c)$ in area: $N c$ is calculated for golden mantellas, as the sum of the change for each future scenario; future increase in area $\left(T_{f i}\right)\left(\mathrm{km}^{2}\right)$ minus future decrease in area $\left(T_{f d}\right)$ over the area under current climate conditions $\left(T_{c}\right)$.

Equation 1.

$$
N c=\sum \frac{\left(T_{f i}-T_{f d}\right)}{T_{c}}
$$

We used Protected Planet (2021) to identify the protected areas networks. Finally, we assessed how well the current system of protected area networks surrounding golden mantella area of occupancy accounts for golden mantella distribution in both current and future climate scenarios. To do this, we calculated for each scenario, the simple metric of area of suitable habitat within the protected area network/total area of suitable habitat using ARCGIS proTM.

\section{RESULTS}

Our model demonstrated a good fit with the data (AUC $=0.994, \mathrm{SD}=0.001$ ) and showed that two main drivers influence $M$. aurantiaca distributions under current climatic conditions: landcover (contributed $32 \%$ to the final model) and the length and severity of the dry season (water deficit; model contribution: $31 \%$ ) (Fig. 1). Mean temperature of the warmest quarter contributed $24 \%$ to the final model, whilst all other variables each contributed $<2 \%$ to the final model except mean rainfall of the wettest quarter $(<9 \%)$. Golden mantellas are found mainly in broadleaved evergreen forest (rainforest) and only have a narrow tolerance of extended dry conditions. The potential distribution of golden mantellas under current climate conditions extends outside the current MCP (Fig. 3) with potentially highly suitable habitat occurring in a narrow south-west to north-east band 


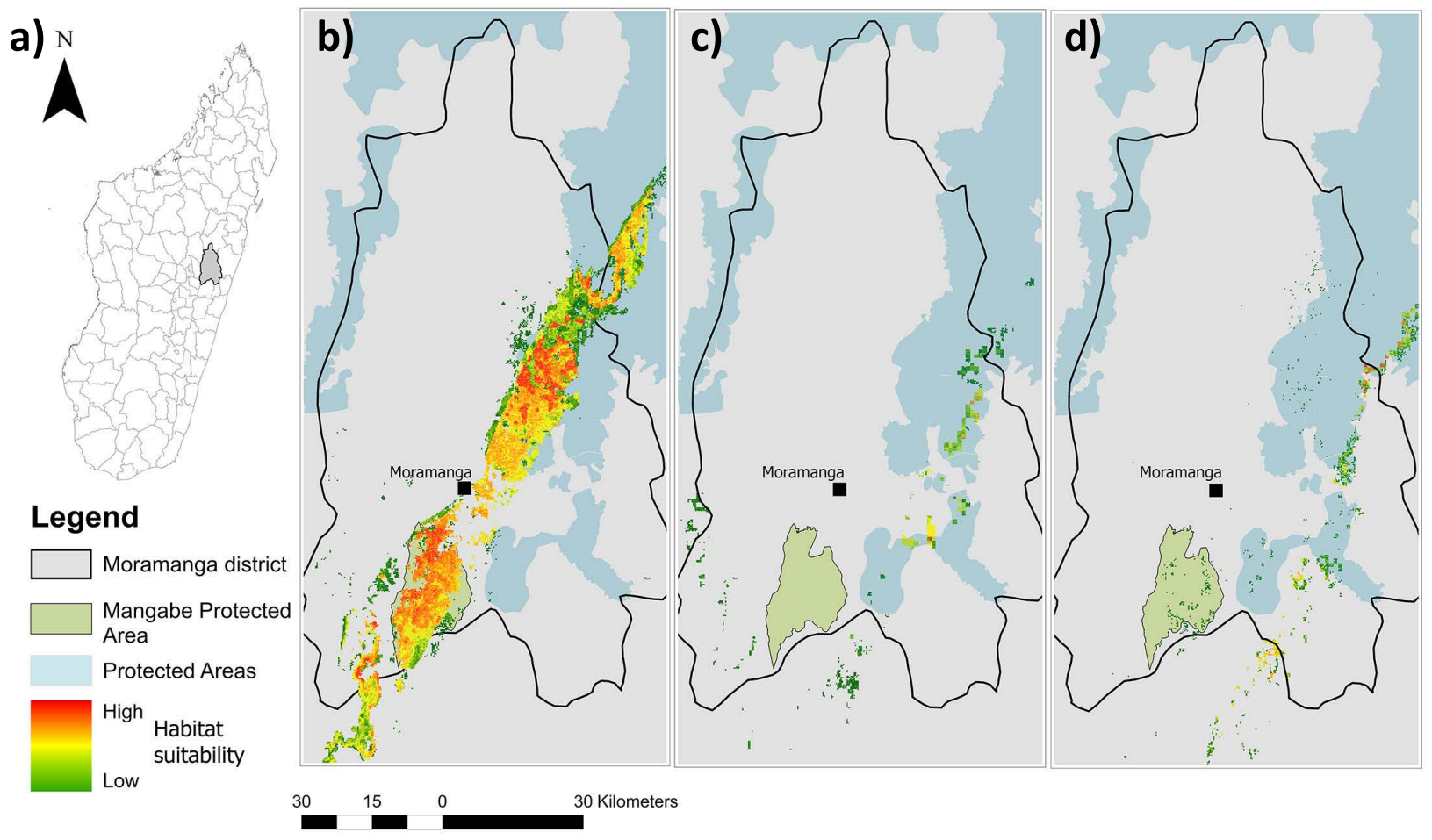

Figure 3. Species Distribution Modelling for the golden mantella showing (a) political divisions with Moramanga highlighted in grey with a black border; (b) potential distribution under current climate; potential distributions under (c) RCP 4.5, 2085 and (d) RCP 8.5, 2085, showing decrease in range and shift in a south-easterly direction.

divided into two distinct areas. These areas embrace the two known population centres for golden mantellas: Mangabe in the south and Torotorofotsy/Analamay in the north. From our models, local protected areas currently offer protection to $24 \%$ of potentially suitable habitat for golden mantellas. As climate changes, so does the distribution of golden mantellas, with the area of suitable habitat decreasing from $2,110 \mathrm{~km}^{2}$ (current climate) to $121 \mathrm{~km}^{2}(=-0.94)$ and $138 \mathrm{~km}^{2}(=-0.93)$ (RCP 4.5 and 8.5 respectively; Fig. 3). Furthermore, occupancy of suitable protected area decreases by $86 \%$ for both climate scenarios. Slightly larger areas of suitable habitat predicted under the higher RCP 8.5 scenario would seem counter-intuitive, however it may be that more variation in topography or changes in range and availability of water at higher altitudes increases available area. Equally, although the overall distribution within protected areas is reduced, more of the range is shifted into existing protected areas under RCP 8.5 than under RCP 4.5 (see later discussion). Further, we observed a range shift under scenarios RCP 4.5 and RCP 8.5 to the south-east of the current distribution by $10-15 \mathrm{~km}$ (Fig. 3). Within the projected habitat distribution range under RCP 4.5 and 8.5 , there are several areas that are predicted to be climatically stable (Fig. 4). By climatically stable we mean consistently provides areas of suitable habitat for golden mantellas across climate scenarios. Assuming landcover is appropriate, the areas predicted here could also provide suitable habitat in terms of water deficit i.e. the range of water deficit stays within the boundaries needed by golden mantellas.

\section{DISCUSSION}

We investigated whether projected climate change scenarios would influence current golden mantella population distributions in rainforest habitat in Madagascar. Our results suggest golden mantella population distribution is driven by the type of available habitat and the amount of water retained within those habitats. Our models predict that as the length and severity of the dry season increases, the availability of suitable habitat for golden mantellas decreases by more than $93 \%$, from $2110 \mathrm{~km}^{2}$ currently to $121 \mathrm{~km}^{2}$ under RCP 4.5 , and to $138 \mathrm{~km}^{2}$ under RCP 8.5 by 2085 . Consequently, less than $7 \%$ of currently available suitable habitat is likely to remain suitable under these scenarios. We also reveal that local protected areas currently offer protection to $24 \%$ of potentially suitable habitat for golden mantellas. Models predict that the distribution of viable habitat will shift $10-15 \mathrm{~km}$ away from its current location with the majority ( $86 \%$ ) falling outside of protected areas.

The northern part of the RCP 8.5 projection falls within the Corridor Ankeniheny-Zahamena (CAZ) protected area. Covering some $3691 \mathrm{~km}^{2}, \mathrm{CAZ}$ is one of the largest areas of rainforest in Madagascar and comprises a core protected area and sustainable use near the boundary. Likewise, the southern part of the RCP 8.5 projection falls within the Mangabe protected area which also includes a core protected zone and areas of sustainable use. In contrast, the projections of the RCP 4.5 model place the future distribution of golden mantellas outside protected areas.

Increased temperatures and reduced rainfall will 


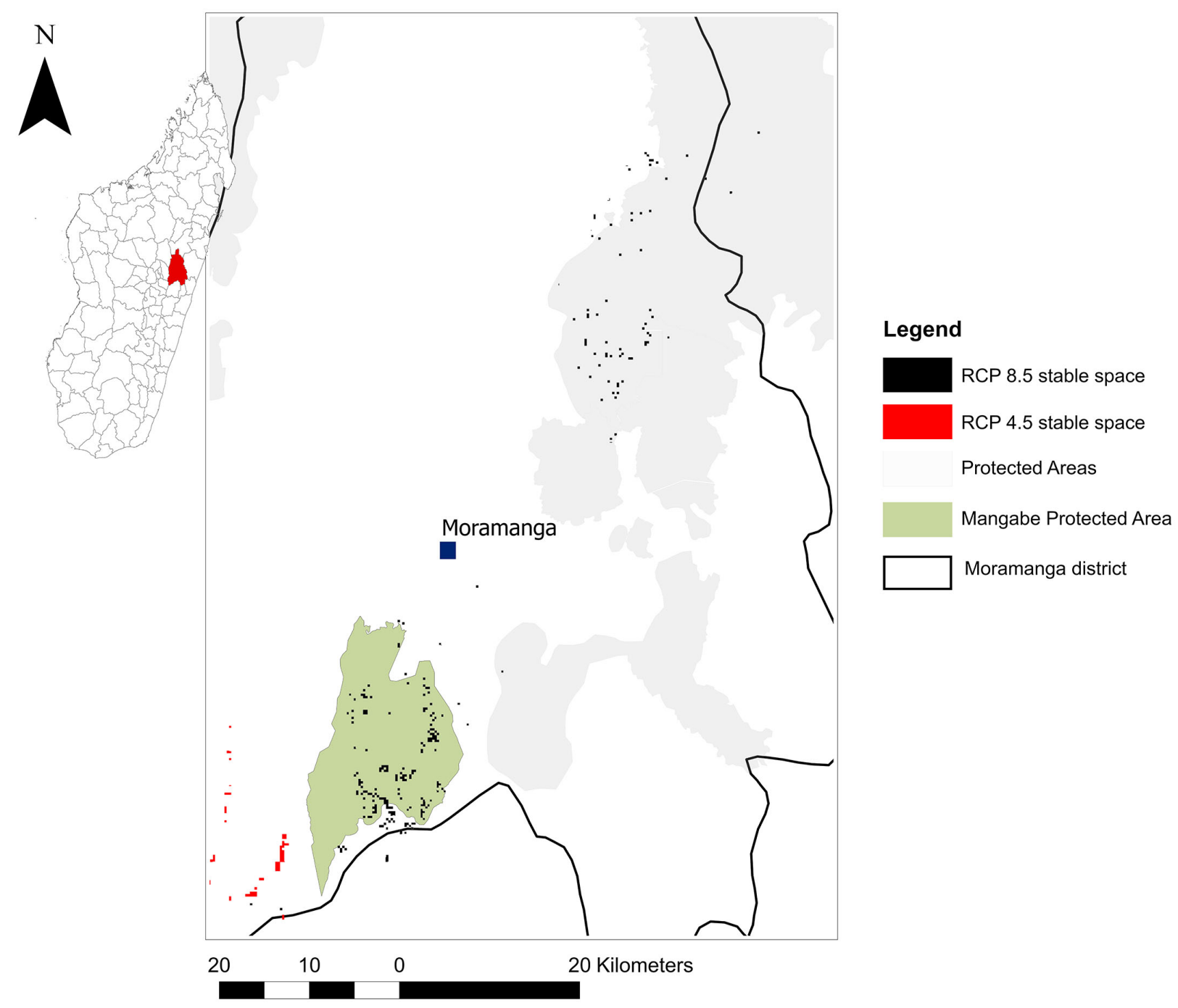

Figure 4. Climate stable spaces predicted within the range of projected distributions for RCP 4.5 and RCP 8.5. Protected areas are shown as light grey, with Mangabe (protected area that covers most of the current distribution of $M$. aurantiaca) highlighted in light green.

change forest habitat by restricting the availability of moisture to vegetation, soil and substrate (Bartelt et al., 2010). As microhabitat becomes warmer and drier the opportunity for thermoregulation and hydroregulation become more challenging. Frogs lose water quickly from the skin by evaporation, and to mitigate this loss they need to find moist habitat in which to take up water at least as quickly as it is being lost (Duellman \& Trueb, 1994). Several studies have found that montane amphibians may shift range upslope to cooler areas when exposed to prolonged ambient temperature rises (Raxworthy et al., 2008). However, this is not an option for golden mantellas as they already live at, or close to, the crests of the slopes they inhabit. Further, although golden mantellas are known to migrate a few hundred metres between the crest and breeding ponds (Piludu et al., 2015), rather less is known regarding their long-range dispersal ability. Current mantella forest habitat is also highly fragmented and usually bordered by agricultural land or deforested areas. Consequently, land use other than forest may well prevent range expansion or shift to track preferred environmental variables. Indeed,
Harrison et al. (2006) state that where a species is in decline they may not automatically shift or expand their current range to track preferred climatic variables. Willis et al. (2015) advise that if climate suitability changes markedly within a species' current distribution and there is no suitable climate/habitat within realistic colonisation range, then translocation to suitable areas should be considered. Indeed, rigorous habitat assessment should be an essential precursor for any translocation. Equally, any translocation strategy should assess the risks, benefits and cost-effectiveness of alternative approaches, such as whether stock should be sourced from captive breeding populations or non-threatened wild populations (Harding et al., 2016).

SDM results identify several locations considered climatically stable and relatively close (within the Moramanga area) to current golden mantella distributions (Fig. 4). However, most of the predicted stable areas are thought to contain degraded forest or agricultural fields (Pers. Comm. J.Razafimanahaka, 2021). Ideally, we would hope to survey those new sites and other areas in between current and potential distributions to ascertain 
if there is a realistic opportunity to develop wildlife corridors, which may facilitate golden mantella range shift.

There is already a programme of survey and research which seeks new areas in which to create, restore or protect breeding ponds and habitat (Piludu et al., 2015); however, in light of our current findings, it may be prudent to consider searching further afield for new potential sites. Our results suggest these new sites should be sought a further $10-15 \mathrm{~km}$ south-east from current golden mantella distributions.

The complexity of biological interactions between species, environment and anthropogenic influence over time means there are constraints on the accuracy of any prediction we may make (Harrison et al., 2006). However, climate change is already impacting heavily on species and ecosystems (Hannah et al., 2008; Raxworthy et al., 2008; Tadross et al., 2008), and as such conservation actions should be planned and carried out without delay using the knowledge and techniques we do have, rather than wait until more advanced methods become available (Rowland et al., 2011).

We therefore recommend carrying out surveys to test whether newly highlighted areas identified as climatically stable or within projected distribution under climate change have the potential for translocation of golden mantellas. Where appropriate, this may involve habitat restoration to ensure water bodies for breeding and appropriate associated microhabitat (Edwards et al., 2019). Further research should be conducted into the feasibility of placing wildlife corridors between current and potential golden mantella distribution to facilitate range shift to safer areas. Expanding protection and status to potential climate stable areas and projected population distribution ranges should also be a priority.

\section{ACKNOWLEDGEMENTS}

This research was partly funded by the Darwin Initiative and Chester Zoo. We thank Lee Brady, Gerardo Garcia, Helena Turner, and Christian Randrianantoandro for assistance in the field. Phil Platts (University of York) kindly assisted and advised on raster development. Thanks also to local guides and patrollers for their help with data collection. We are also very grateful to the Malagasy Government for providing research permits N209/13/MEEF/SG/DGF/DCB.SAP/SCB and N314/14/ MEEF/SG/DGF/DCB.SAP/SCB.

\section{Data Accessibility}

Detailed site data for golden mantellas is restricted and sensitive due to their Critically Endangered (CR) status and ongoing susceptibility to collection for the pet trade. Climate data was sourced from Worldclim (See: Hijmans et al., 2005) and AFRICLIM (See: Platts et al., 2015). Data downloaded/used in analysis from Worldclim are given in Table 1. Protected areas shape file for figures were courtesy of Protected Planet (2021).

\section{REFERENCES}

Arino, O., Perez, R., Julio, J., Vasileios, K., Bontemps, S., Defourny, P., \& Van Bogaert, E. (2012). Global Land Cover Map for 2009 (GlobCover 2009). European Space Agency (ESA) \& Université catholique de Louvain (UCL), PANGAEA. DOI: 10.1594/PANGAEA.787668

Bartelt, P.E., Klaver, R.W. \& Porter, W.P. (2010). Modeling amphibian energetics, habitat suitability, and movements of western toads, Anaxyrus (= Bufo) boreas, across present and future landscapes. Ecological Modelling 221, 26752686.

Bateman, B.L., Murphy, H.T., Reside, A.E., Mokany, K. \& VanDerWal, J. (2013). Appropriateness of full-, partial-and no-dispersal scenarios in climate change impact modelling, Diversity and Distributions 19, 1224-1234.

Blank, L. \& Blaustein, L. (2012). Using ecological niche modeling to predict the distributions of two endangered amphibian species in aquatic breeding sites. Hydrobiologia 693, 157167.

Brown, K.A., Parks, K.E., Bethell, C.A., Johnson, S.E. \& Mulligan, M. (2015). Predicting plant diversity patterns in Madagascar: understanding the effects of climate and land cover change in a biodiversity hotspot. PloS one 10, e0122721.

Bungard, M. (2020). Predictive modelling for anuran responses to climate change in tropical montane ecosystems. PhD thesis, University of York.

Cao, Y., DeWalt, R.E., Robinson, J.L., Tweddale, T., Hinz, L. \& Pessino, M. (2013). Using Maxent to model the historic distributions of stonefly species in Illinois streams: the effects of regularization and threshold selections. Ecological Modelling 259, 30-39.

Chunco, A.J., Phimmachak, S., Sivongxay, N. \& Stuart, B.L. (2013). Predicting environmental suitability for a rare and threatened species (Lao Newt, Laotriton laoensis) using validated species distribution models. PloS one 8, e59853.

Cushman, S.A. (2006). Effects of habitat loss and fragmentation on amphibians: A review and prospectus. Biological Conservation 128, 231-240.

Didan, K., Munoz, A.B., Solano, R. \& Huete, A. (2015). MODIS vegetation index user's guide (MOD13 series), Vegetation Index and Phenology Lab, The University of Arizona, pp. 1-38.

Duellman, W.E. \& Trueb, L. (1994). Biology of amphibians, JHU press.

Echeverria, C., Coomes, D., Salas, J., Rey-Benayas, J.M., Lara, A. \& Newton, A. (2006). Rapid deforestation and fragmentation of Chilean temperate forests. Biological Conservation 130, 481-494.

Edwards, W.M., Griffiths, R.A., Bungard, M.J., Rakotondrasoa, E.F. Razafimanahaka, J.H., Razafindraibe, P., Andriantsimanarilafy, R.R., \& Randrianantoandro, J.C. (2019). Microhabitat preference of the critically endangered golden mantella frog in Madagascar. Herpetological Journal 29, 207-213.

Elith, J., Phillips, S.J., Hastie, T., Dudík, M., Chee, Y.E. \& Yates, C.J. (2011). A statistical explanation of MaxEnt for ecologists. Diversity and Distributions 17, 43-57.

ESRI (2015). ArcGIS Desktop: Release 10.3.1. Redlands, CA: Environmental Systems Research Institute.

Fourcade, Y., Engler, J.O., Rödder, D. \& Secondi, J. (2014). Mapping species distributions with Maxent using a geographically 
biased sample of presence data: a performance assessment of methods for correcting sampling bias. PloS one 9, e97122.

Glaw, F. \& Vences, M. (2007). A field guide to the amphibians and reptiles of Madagascar, Vences \& Glaw.

Groff, L.A., Marks, S.B. \& Hayes, M.P. (2014). Using ecological niche models to direct rare amphibian surveys: A case study using the Oregon Spotted Frog (Rana pretiosa). Herpetological Conservation and Biology 9, 354-368.

Hannah, L., Dave, R., Lowry, P.P, Andelman, S., Andrianarisata, M., Andriamaro, L., Cameron, A., Hijmans, R., Kremen, C., MacKinnon, J., Randrianasolo, H.H., Andriambololonera, S., Razafimpahanana, A., Randriamahazo, H., Randrianarisoa, J., Razafinjatovo, P., Raxworthy, C., Schatz, G.E., Tadross, M. \& Wilmé, L. (2008). Climate change adaptation for conservation in Madagascar. Biology Letters 4, 590-594.

Harding, G., Griffiths, R.A. \& Pavajeau, L. (2016). Developments in amphibian captive breeding and reintroduction programs. Conservation Biology 30, 340-349.

Harrison, P., Berry, P., Butt, N. \& New, M. (2006). Modelling climate change impacts on species' distributions at the European scale: implications for conservation policy. Environmental Science \& Policy 9, 116-128.

Hernandez, P.A., Graham, C.H., Master, L.L. \& Albert, D.L. (2006). The effect of sample size and species characteristics on performance of different species distribution modeling methods. Ecography 29, 773-785.

Hijmans, R.J., Cameron, S.E., Parra, J.L., Jones, P.G. \& Jarvis, A. (2005). Very high-resolution interpolated climate surfaces for global land areas. International Journal of Climatology 25, 1965-1978.

IUCN, (2021). The IUCN Red List of Threatened Species. Version (2020-23). http://iucnredlist.org. Downloaded on 10th March 2021.

Liu, C., Berry, P.M., Dawson, T.P. \& Pearson, R.G. (2005). Selecting thresholds of occurrence in the prediction of species distributions. Ecography 28, 385-393.

Márcia-Barbosa, A., Real, R., Muñoz, A. \& Brown, J.A. (2013). New measures for assessing model equilibrium and prediction mismatch in species distribution models. Diversity and Distributions 19, 1333-1338.

Merow, C., Smith, M.J. \& Silander, J.A. (2013). A practical guide to MaxEnt for modeling species' distributions: what it does, and why inputs and settings matter. Ecography 36, 10581069.

Meynard, C.N., Migeon, A. \& Navajas, M. (2013). Uncertainties in predicting species distributions under climate change: $\mathrm{A}$ case study using Tetranychus evansi (Acari: Tetranychidae), a widespread agricultural pest. PLoS One 8, e66445.

Myers, N., Mittermeier, R.A., Mittermeier, C.G., Da Fonseca, G.A. \& Kent, J. (2000). Biodiversity hotspots for conservation priorities. Nature 403, 853-858.

NASA/METI/AIST/Japan Spacesystems and U.S./Japan ASTER Science Team (2001) ASTER DEM Product. distributed by NASA EOSDIS Land Processes DAAC. DOI: 10.5067/ASTER/ AST14DEM.003.

ORNL DAAC (2017). Spatial Data Access Tool (SDAT). Oak Ridge, Tennessee, USA: ORNL DAAC. DOI: 10.3334/ ORNLDAAC/1388.

Pearson, R.G. (2007). Species distribution modelling for conservation educators and practitioners. Synthesis American Museum of Natural History, vol. 50.
Pfeifer, M., Disney, M., Quaife, T. \& Marchant, R. (2012). Terrestrial ecosystems from space: a review of earth observation products for macroecology applications. Global Ecology and Biogeography 21, 603-624.

Pfeifer, M., Gonsamo, A., Woodgate, W., Cayuela, L., Marshall, A.R., Ledo, A., Paine, T.C.E., Marchant, R., Burt, A., Calders, K., Courtney-Mustaphi, C., Cuni-Sanchez, A., Deere, N.J., Denu, D., de Tanago, J.G., Hayward, R., Lau, A., Macía, M.J., Olivier, P.I., Pellikka, P., Seki, H., Shirima, D., Trevithick, R., Wedeux, B., Wheeler, C., Munishi, P.K.T., Martin, T., Mustari, A. \& Platts, P.J. (2018). Tropical forest canopies and their relationships with climate and disturbance: results from a global dataset of consistent field-based measurements. Forest Ecosystems 5, 1-14.

Phillips, S.J., Anderson, R.P. \& Schapire, R.E. (2006). Maximum entropy modelling of species geographic distributions. Ecological Modelling 190, 231-259.

Piludu, N., Dubos, N., Razafimanahaka, J.H., Razafindraibe, P., Randrianantoandro, J.C. \& Jenkins, R.K. (2015). Distribution, threats and conservation of a Critically Endangered amphibian (Mantella aurantiaca) in Eastern Madagascar. Herpetology Notes, 8, 119-123.

Platts, P.J., Omeny, P.A. \& Marchant, R. (2015). AFRICLIM: highresolution climate projections for ecological applications in Africa. African Journal of Ecology 53, 103-108.

Protected Planet, UNEP-WCMC \& IUCN world database on protected areas. Version (2021). www.protectedplanet.net. Downloaded on 07/03/2021.

Raxworthy, C.J., Pearson, R.G., Rabibisoa, N., Rakotondrazafy, A.M., Ramanamanjato, J., Raselimanana, A.P., Wu, S., Nussbaum, R.A. \& Stone, D.A. (2008). Extinction vulnerability of tropical montane endemism from warming and upslope displacement: a preliminary appraisal for the highest massif in Madagascar. Global Change Biology 14, 1703-1720.

Rodríguez-Rey, M., Jiménez-Valverde, A. \& Acevedo, P. (2013). Species distribution models predict range expansion better than chance but not better than a simple dispersal model. Ecological Modelling 256, 1-5.

Rowland, E.L., Davison, J.E. \& Graumlich, L.J. (2011). Approaches to evaluating climate change impacts on species: a guide to initiating the adaptation planning process. Environmental Management 47, 322-337.

Seidl, R., Thom, D., Kautz, M., Martin-Benito, D., Peltoniemi, M., Vacchiano, G., Wild, J., Ascoli, D., Petr, M. \& Honkaniemi, J. (2017). Forest disturbances under climate change. Nature Climate Change 7, 395-402.

Sharifi, M., Karami, P., Akmali, V., Afroosheh, M. \& Vaissi, S. (2017). Modeling geographic distribution for the endangered yellow spotted mountain newt, Neurergus microspilotus (Amphibia: Salamandridae) in Iran and Iraq. Herpetological Conservation and Biology 12, 488-497.

Simard, M., Pinto, N., Fisher, J.B. \& Baccini, A. (2011). Mapping forest canopy height globally with spaceborne lidar. Journal of Geophysical Research: Biogeosciences, 116(4), 1-12. DOI: 10.1029/2011JG001708.

Smith, M.A. \& Green, D.M. (2005). Dispersal and the metapopulation paradigm in amphibian ecology and conservation: are all amphibian populations metapopulations? Ecography 28, 110-128.

Stanton, J.C., Pearson, R.G., Horning, N., Ersts, P. \& Reşit 
Akçakaya, H. (2012). Combining static and dynamic variables in species distribution models under climate change. Methods in Ecology and Evolution 3, 349-357.

Stephenson, N. (1998). Actual evapotranspiration and deficit: biologically meaningful correlates of vegetation distribution across spatial scales. Journal of Biogeography 25, 855-870.

Tadross, M., Randriamarolaza, L., Rabefitia, Z. \& Zheng, K. (2008). Climate change in Madagascar; recent past and future, Washington DC (World Bank).

Van Vuuren, D.P., Edmonds, J., Kainuma, M., Riahi, K., Thomson, A., Hibbard, K., Hurtt, G.C., Kram, T., Krey, V. \& Lamarque, J. (2011). The representative concentration pathways: an overview. Climatic Change 109, 5-31.

Vieilledent, G., Grinand, C., Rakotomalala, F.A., Ranaivosoa, R., Rakotoarijaona, J., Allnutt, T.F. \& Achard, F. (2018). Combining global tree cover loss data with historical national forest cover maps to look at six decades of deforestation and forest fragmentation in Madagascar, Biological Conservation 222, 189-197.
Vieilledent, G., Grinand, C. \& Vaudry, R. (2013). Forecasting deforestation and carbon emissions in tropical developing countries facing demographic expansion: a case study in Madagascar. Ecology and Evolution 3, 1702-1716.

Warren, D.L., Glor, R.E. \& Turelli, M. (2010). ENMTools: a toolbox for comparative studies of environmental niche models. Ecography 33, 607-611.

Warren, D.L. \& Seifert, S.N. (2011). Ecological niche modeling in Maxent: the importance of model complexity and the performance of model selection criteria. Ecological Applications 21, 335-342.

Willis, S., Foden, W., Baker, D., Belle, E., Burgess, N., Carr, J., Doswald, N., Garcia, R., Hartley, A. \& Hof, C. (2015), Integrating climate change vulnerability assessments from species distribution models and trait-based approaches. Biological Conservation 190, 167-178.

Accepted: 29 September 2020 